\title{
Storm origin of bone-bearing beds in the Lower Devonian placoderm sandstone from Podłazie Hill (Holy Cross Mountains, central Poland)
}

\author{
Piotr SZREK ${ }^{1, *}$, Grzegorz NIEDŹWIEDZKI ${ }^{2}$ and Marek DEC ${ }^{3}$ \\ 1 Polish Geological Institute-National Research Institute, Rakowiecka 4, 00-975 Warszawa, Poland \\ 2 Uppsala University, Department of Organismal Biology, Evolutionary Biology Centre, Norbyvägen 18A, 752-36 Uppsala, \\ Sweden \\ 3 Polish Academy of Sciences, Institute of Paleobiology, Twarda 51/55, 00-818 Warszawa, Poland
}

Szrek, P., Niedźwiedzki, G., Dec, M., 2014. Storm origin of bone-bearing beds in the Lower Devonian placoderm sandstone from Podłazie Hill (Holy Cross Mountains, central Poland). Geological Quarterly, 58 (4): 795-806, doi: 10.7306/gq.1191

\begin{abstract}
The placoderm sandstone (Emsian, Holy Cross Mountains) exposed in the abandoned quarry at Podłazie Hill was revisited and excavated during fieldwork conducted in 2011-2013. Bone-bearing breccias were studied in details for the first time at this site and subjected to taphonomic analysis. Vertebrate remains are dominated by heterostracans, while true placoderms compose less than $20 \%$ of the total vertebrate assemblage. The high degree of fragmentation of the bones and low degree of abrasion indicate that the remains were reworked and transported before final burial. This is consistent with the mixed character of the bone accumulations, which comprise both open-shelf forms (acanthodians, chondrichthyans) as well as those related to marginal-marine environments (placoderms and sarcopterygians). The bone-bearing succession has been subdivided into five depositional facies attributed to a coastal lagoon influenced by stormy, possibly tidal conditions. The occurrence of the invertebrate trace fossil IImenichnus sp. accompanied by Lockeia and Monomorphichnus supports this interpretation.
\end{abstract}

Key words: placoderm sandstone, Lower Devonian, Emsian, Holy Cross Mountains.

\section{INTRODUCTION}

In this paper, new data on Lower Devonian deposits are presented and focused on the origin of the bone-bearing breccia deposits known for more than one hundred years as the "Placoderm Sandstone" (Gürich, 1896; Czarnocki, 1919, 1936). The siliciclastic deposits of the Lower Devonian of the Holy Cross Mountains (central Poland) are renowned for abundant fish fossils, including jawless fishes and early gnathostomes (Tarlo, 1957, 1961, 1964, 1965; Kulczycki, 1960; Szrek et al., 2012, in press). Here, we present the first detailed taphonomic study of the vertebrate accumulations in Emsian deposits exsposed in the abandoned quarry at Podłazie Hill (Fig. 1).

The Lower Devonian deposits in the Kielce Region of the Holy Cross Mountains are strongly reduced in thickness (0-250 m) in contrast to the Łysogóry Region where the succession is up to $550 \mathrm{~m}$ thick (Tarnowska, 1981; Fig. 2). The occurrence of fish fossils is so characteristic of the Lower Devonian in the Kielce Region that the strata containing them were

\footnotetext{
* Corresponding author, e-mail: piotr.szrek@pgi.gov.pl
}

Received: February 4, 2014; accepted: June 11, 2014; first published online: September 15, 2014 distinguished informally as the Placoderm Sandstone Formation (Gürich, 1896; Czarnocki, 1919). The presence of vertebrate fossils defined collectively as "placoderms" was also thought to be significant stratigraphically (Czarnocki 1919, 1936). In spite of many years of research on the genesis of the Lower Devonian placoderm-bearing rocks, their genesis has not been resolved. Many descriptions of the agnathan remains by Tarlo $(1957,1961,1964,1965)$ and a single description of a large sarcopterygian fish by Kulczycki (1960) have been completed, but none of the placoderm specimens recovered have been formally described. Recently, in 2011-2013, a large number of a newly-collected material by the authors of this paper has been added including jawless fishes such as heterostracans and jawed fishes such as chondrichthyans, acanthodians, sarcopterygians, actinopterygians and remains of placoderms. All material collected and described by these authors (see Czarnocki, 1919, 1936), as well as the newest collection, have been obtained from the same locality at Podłazie Hill. In the past this locality was incorrectly called Świnia Mountain, which is in fact located $1 \mathrm{~km}$ to the east of Podłazie Hill, or simply as Daleszyce (Fig. 1).

The fossiliferous Podłazie Hill site was investigated for the first time during the summers of 1955 and 1956 by the Paleontological Institute (Warsaw University). Further collections from this site were made by Łobanowski and Tarlo in 1958. The vertebrate remains collected were initially identified by scientists from the British Museum (Natural History Museum, London). 


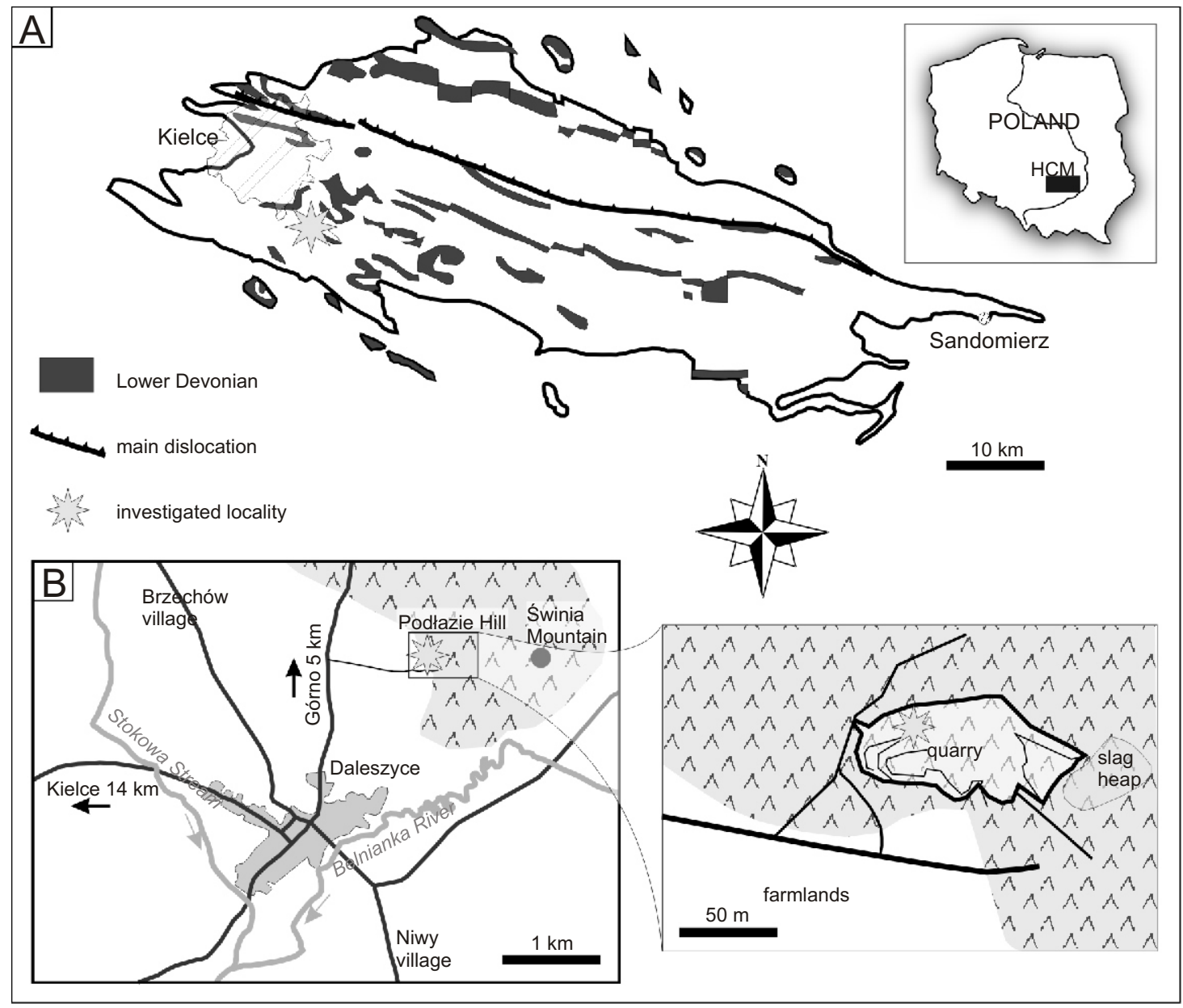

Fig. 1. Geographical setting of the site investigated: A - location of Podłazie Hill in the Holy Cross Mountains (HCM), central Poland, B - sketch map of Daleszyce with the position (magnified part) the re-studied abandoned quarry at Podłazie Hill
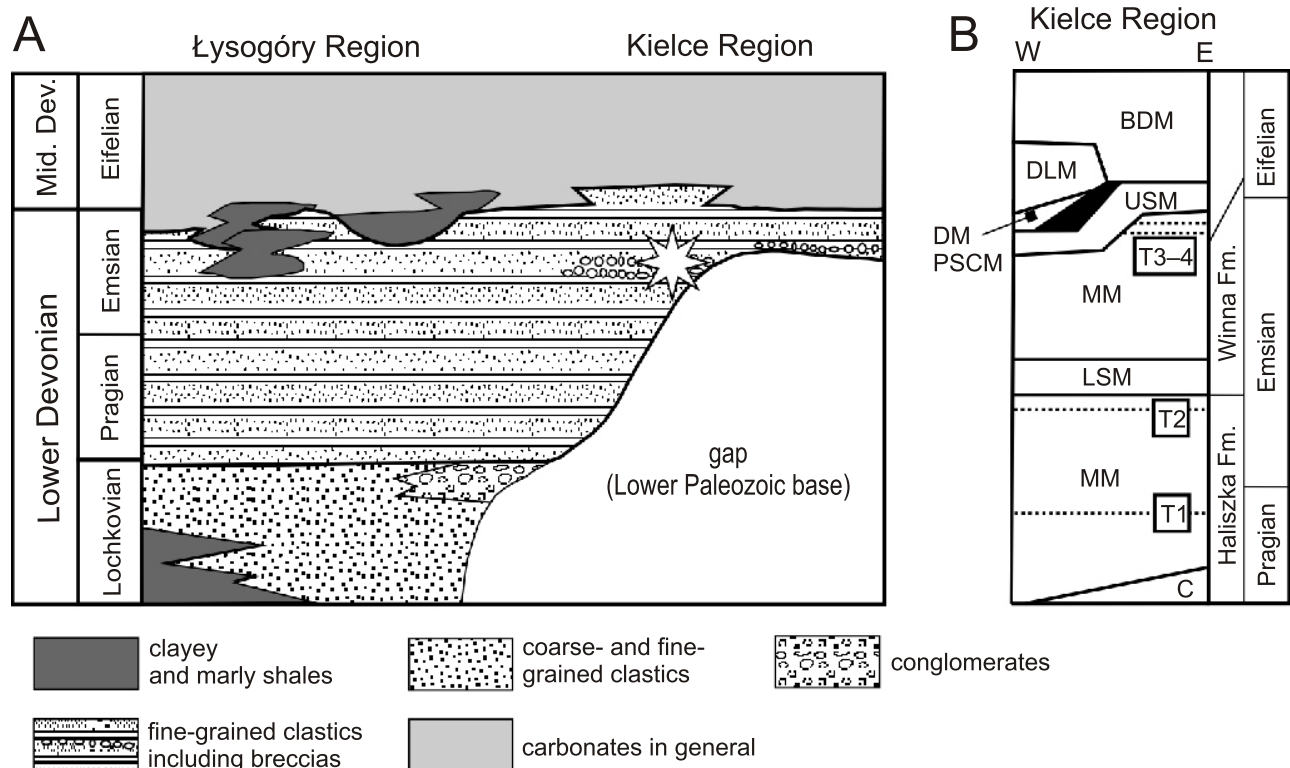

coarse- and finegrained clastics

Fig. 2. Diagrammatic cross-section through the Holy Cross Mountains from the base to the top of the Lower Devonian (after Szulczewski, 1995, modified) with the probable position of the locality investigated (A) and lithostratigraphy of the Upper Pragian to Eifelian in the Kielce Region (B) modified from Fijałkowska-Mader and Malec (2011)

BDM - bioturbated dolomite member; C - conglomerate; DLM - Dąbrowa Limestone Member; DM - dolomite member; LSM - lower sandstone member; MM - mudstone member; PSCM - pyrite-bearing and sideritic claystone member; USM - upper sandstone member; T1-4 - pyroclastic horizons; black area in $B$ is a stratigraphical gap 
This paper presents the results of a detailed study of an exceptional en masse occurrence and accumulation of vertebrate bones in a siliciclastic bone-bearing breccia called the placoderm sandstone. Breccia beds are known from numerous localities scattered throughout the entire Lower Devonian succession of the Kielce Region, but the Podłazie Hill site reveals an exceptionally large mass occurrence of fossils. The largest amount of Lower Devonian vertebrate remains in Poland comes from this site, but many new vertebrate fossils have been recovered from other Lower Devonian localities and lithostratigraphic horizons in the Holy Cross Mountains (Szrek et al., 2012, in press).

This paper also discusses the first results of taphonomic analysis of the vertebrate assemblage from the Podłazie Hill site, which may be helpful for other palaeoecological studies of the Pragian and Emsian agnathan and gnathostome communities of the Holy Cross Mountains and elsewhere.

\section{REGIONAL GEOLOGICAL SETTING}

The Lower Devonian succession in the Kielce Region (Fig. 2) consists of sandstones and mudstones, subordinately intercalated with siltstones, claystones and conglomerates, and spans the earliest Pragian to Emsian (Fijałkowska-Mader and Malec, 2011). Well-cemented, white, yellowish or light grey quartzitic sandstones have been traditionally interpreted as formed in shallow-marine and transitional, paralicenvironments (Czarnocki, 1936; Tarnowska, 1976).

The Lower Devonian deposits in the Kielce Region lie unconformably on various units of the Lower Paleozoic Czarnocki 1936: Kowalczewski. 1971: Tarnowska. 1976: Głazek et al., 1981 Szulczewski, 1995 Fijałkowska-Mader and Malec, 2011). The succession was informally divided into the Haliszka and Winna formations, further subdivided into the lower sandstone member, mudstone member and upper sandstone member (Tarnowska, 1976, 1981, 1987). In the Kielce area, the Lower Devonian siliciclastic deposits (upper sandstone member) are overlain by the pyrite-bearing and sideritic claystone member, the dolomite member, the Dabrowa Limestone Member and the bioturbated dolomite member (Giirich 1896. Czarnocki 1919. Tarnowska, 1976; Narkiewicz and Olkowicz-Paprocka, 1983 Malec, 1993) representing either the uppermost Emsian, or lowermost Eifelian (Fijałkowska-Mader and Malec, 2011). The Lower Devonian/Middle Devonian transitional deposits (Emsian/Eifelian boundary interval) in the Kielce Region yielded conodonts from the patulus and partitus zones (Fijałkowska-Mader and Malec, 2011). The Lower Devonian of the Kielce Region is subdivided into four miospore zones: Verrucosisporites polygonalis-Dibolisporites wetteldorfensis, Emphanisporites annulatus-Brochotriletes bellatuIus, Emphanisporites foveolatus-Verruciretusispora dubia and Acinosporites apiculatus-Grandispora protea (FijałkowskaMader and Malec, 2011) suggesting the presence of the uppermost Pragian, Emsian and lowermost Eifelian in the Haliszka and Winna formations.

The Łysogóry facies of the Lower Devonian contain horizons with marine invertebrates (brachiopods, trilq noids) and rare fish remains (Czarnocki, 1936; Szulczewski, 1995). The Lower Devonian deposits from the Kielce Region yielded only vertebrate and plant remains (Tarnowska, 1976).

\section{DESCRIPTION OF THE PODŁAZIE HILL SECTION}

Podłazie Hill is a site located about $2 \mathrm{~km}$ north of the town of Daleszyce, $180 \mathrm{~km}$ south of Warszawa, in the southern part of the Holy Cross Mountains, Poland (51 49' $05^{\prime \prime} \mathrm{N}$; $\left.20^{\circ} 49^{\prime} 20^{\prime \prime} \mathrm{E}\right)$. It is_an abandoned quarry located on the southern slope of the hill (Fig. 1) Currently, the whole quarry is densely overgrown by a 30 year-old pine forest, but weathered sandstones crop out in several places. The once-quarried succession was dominated by thick-bedded quartzitic sandstones, but was not properly documented (M. Tarnowska, 1999, pers. comm.). The locality was described first by Łobanowski (1953, unpublished) during the preparation of the geological map of the Daleszyce area. The succession is considered to be Emsian in age $(4076+26$ $393.3 \pm 1.2 \mathrm{Ma}$; Tarnowska, 1976, 1981; Szulczewski and Porebski, 2008), based on miospores and tephrocorrelation (see Fijałkowska-Mader and Malec, 2011). Simple lithostratigraphic considerations suggest that sandstones exposed at Podłazie Hill belong to the lower part of the Winna Formation (see Fijałkowska-Mader and Malec, 2011).

The section excavated in 2011-2012 is rich in fossils and represents only a small fraction of the entire succession exposed originally during quarrying. The section, ca. $2 \mathrm{~m}$ thick, occurs in the middle part of the southern slope and reveals bedding dipping at tectonically $30^{\circ}$ to the south. The excavation reveals five quartzitic beds, up to $50 \mathrm{~cm}$ thick, which are

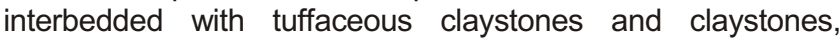
10-15 cm thick (Fig. 3). Each bed tends to begin with an prosionally-based, massive very coarse-grained sandstones or granule conglomerates (quartz grains $3-4 \mathrm{~mm}$ across) and ines upwards into coarse to medium-grained, commonly lamihated sandstones (Fig. 3E). Lamination includes complex ross-laminated lenses, mostly with concave-up set boundaries acking mud drapes (Fig. 3F), and this may represent ummocky-cross-stratification. The sandstone bases are covered in places by relatively rare invertebrate trace fossils (see pescription below).

The rocks in this site dip to the south at about $30^{\circ}$ and mainain a strike of about $190^{\circ}$.

The most conspicuous feature of the sandstone beds is the pccurrence of a basal bone-bearing breccia in their lower part of the section (Fig. 3D). Moreover, two levels rich in fish remains were identified in the section; material derived from one of them was examined in detail (see description below). Breccia interals are $20 \mathrm{~cm}$ thick and show erosional bases (Fig. 3E). The preccia contains broken vertebrate bones (mainly dermal elenents), claystone intraclasts, pebbles (Fig. 4A) and other unidentified elements (Figs. 5-7). There is also a size peparation of particular elements in the breccia seen as gradng. Larger fragments (up to $10 \mathrm{~cm}$ across) tend to occur in the ower part of a bed, whereas the size of clasts and their ampunt decrease upwards and the breccia passes into the topmost, last-free sandy interval (Fig. 3E). Vertebrate remains are paricularly abundant in the upper part of the exposed seqtion Fig. 3).

Vertebrate remains in the breccia are preserved as natural moulds (empty spaces) left after the removal of the bone tissue. The nature of this process is unclear, but it is likely that late diagenetic hydrothermal processes might have been responsible. 

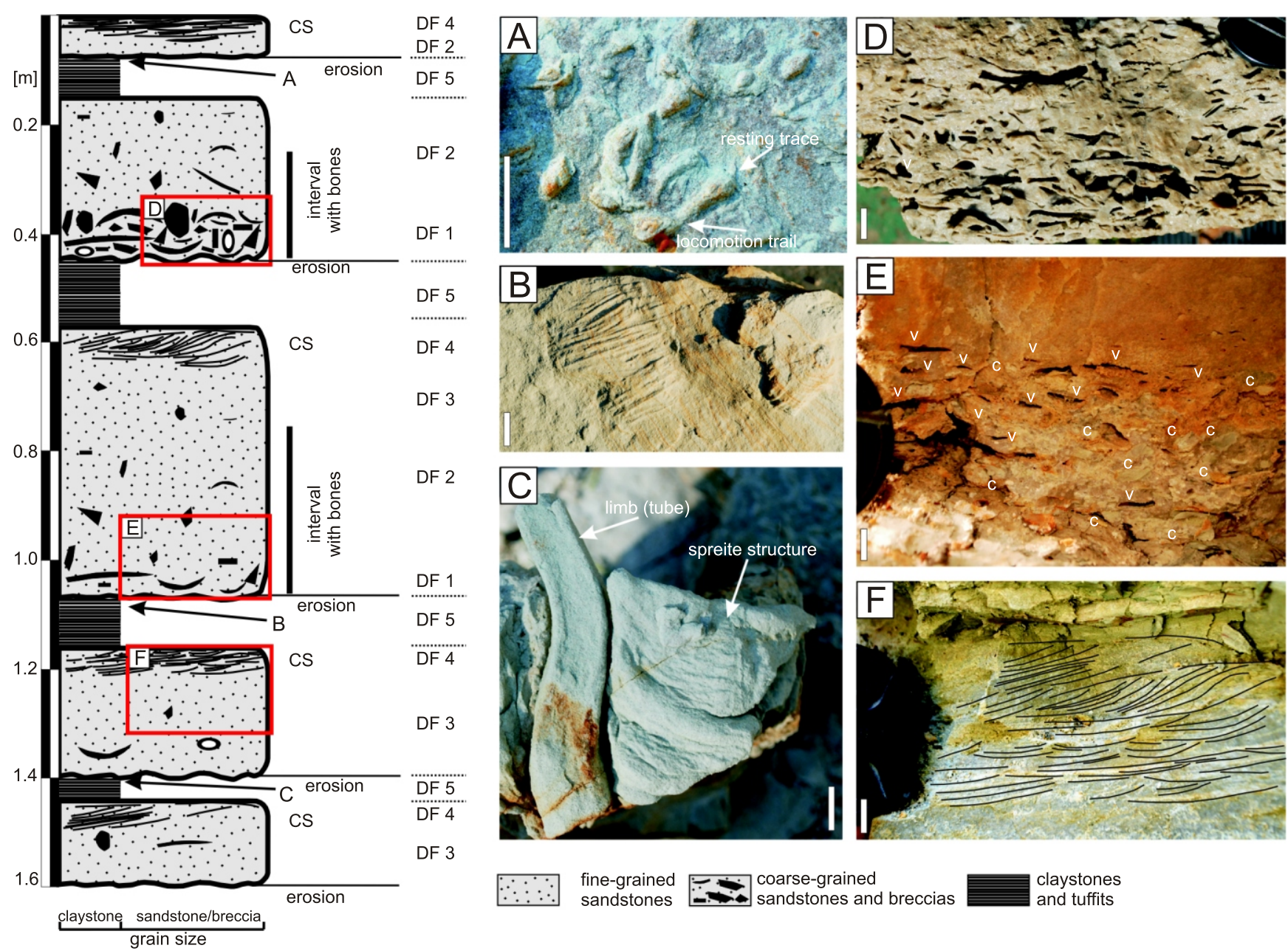

fine-grained
sandstones

coarse-grained

sandstones and breccias

claystones and tuffits

Fig. 3. Lithological profile exposed in the temporary trench at the Podłazie Hill locality

A - Muz. PGI 1755.II.174; Lockeia isp. a part of a surface with resting traces and locomotion trails; B - Muz. PGI 1755.II.151, Monomorphichnus isp.; C - Muz. PGI 1755.II.152, IImenichnus isp.; D - cross-section through the part of bone-bearing breccia richest in vertebrate remains with numerous moulds after bones, spines and clay intraclasts; $\mathbf{E}$ - cross-section through the part of breccia and massive sandstones where numerous clasts and bones in the base of the horizon disappear gradually upwards; $\mathbf{F}$ - cross stratification in the upper part of the bone-bearing breccia; the position of the objects in pictures A-F is marked at the places where they were found; scale bar is $1 \mathrm{~cm}$; $\mathrm{CS}$ - cross stratification, DF - depositional facies; $c$ - clay clasts, $v$ - vertebrate remains

\section{SEDIMENTARY FACIES \\ IN THE PODŁAZIE HILL SECTION}

The placoderm sandstone in the section studied was divided into five depositional facies (A, B, C, D and E; Fig. 4). These appear to be linked up with processes existing within a single depositional environment and may accordingly represent one facies association. However, the limited size of the exposure does not permit investigation of spatial facies variability in any detail.

Facies A (Fig. 4A) consists of breccia layers, 15 to $20 \mathrm{~cm}$ thick, which show usually scoured bases and lenticular to sheet-like geometry. The layers display matrix-supported textures and contain clay intraclasts (Fig. 5B, C), vertebrate reains, inplaces in the form of a mass accumulation (Figs. 5 and (A). and rare quartz pebibles (up to $4 \mathrm{~cm}$ ). The intraclasts vary in size between 0.5 and $15 \mathrm{~cm}$ and reveal in part subrounded to rounded shapes (Figs. 5C and 6C, F). The clasts and vertebrate remains are elther concenthatedin crulde laminae, or arranged randomly throughout the sandy matrix.
Facies B (Fig. 4B) is represented by massive and structureless, fine- to medium-grained sandstones, $10-40 \mathrm{~cm}$ thick. The sandstones contain clay clasts that are isolated or occur in bands. Poorly sorted mixtures of gravel-sized quartz clasts, clay intraclasts and vertebrate remains tend be concentrated near sandstone bases. The massive sandstone passes commonly downwards into the breccia facies.

Facies C (Fig. 4C) comprises layers, $10-15 \mathrm{~cm}$ thick, of very fine to coarse-grained sarddstones, which show plane-parallel lamination and ripple cross-lamination. The sandstones are generally moderately to loфally poorly sorted and contain granule (3-5 mm) stringers.

Facies D (Fig. 4D) contains cross-stratified units, 10 to $15 \mathrm{~cm}$ thick, of well-sorted fine to medium-grained sandstone. Rounded claystone intraclasts tend to be scattered. Facies $\mathrm{E}$ (Fig. 4E) comprises beds, 5 to $15 \mathrm{~cm}$ thick, of largely structureless claystone with tuffite intercalations. Locally, a crude horizontal lamination is discernible due to the presence of very thin silt and sand streaks.

The facies described above are vertically organized into five, roughly fining-upwards unit in erosional bases incised into the claystone facies (Fig. 3). This surface is either 

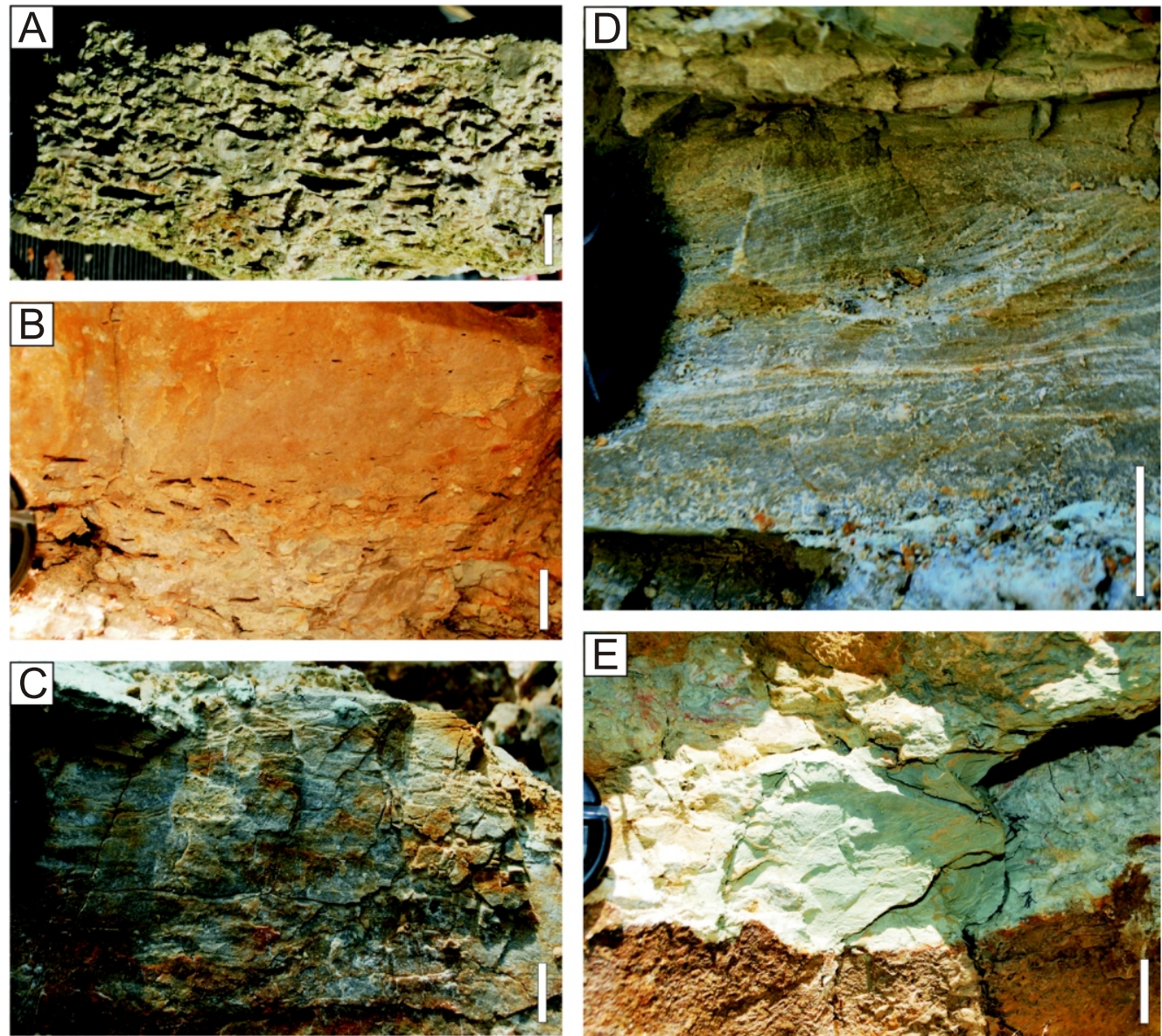

Fig. 4. A representative analysed section illustrating the sedimentology of the bone-bearing interval

A - breccia (depositional facies A); B - massive and structureless, fine- to medium-grained sandstones (depositional facies B); C - very fine- to coarse-grained, plane-parallel laminated sandstones (depositional facies C); D - cross-stratified and structureless fine- to medium-grained, well-sorted sandstones (depositional facies D); $\mathbf{E}$ - massive, usually structureless claystones (depositional facies E); scale bar is $1 \mathrm{~cm}$
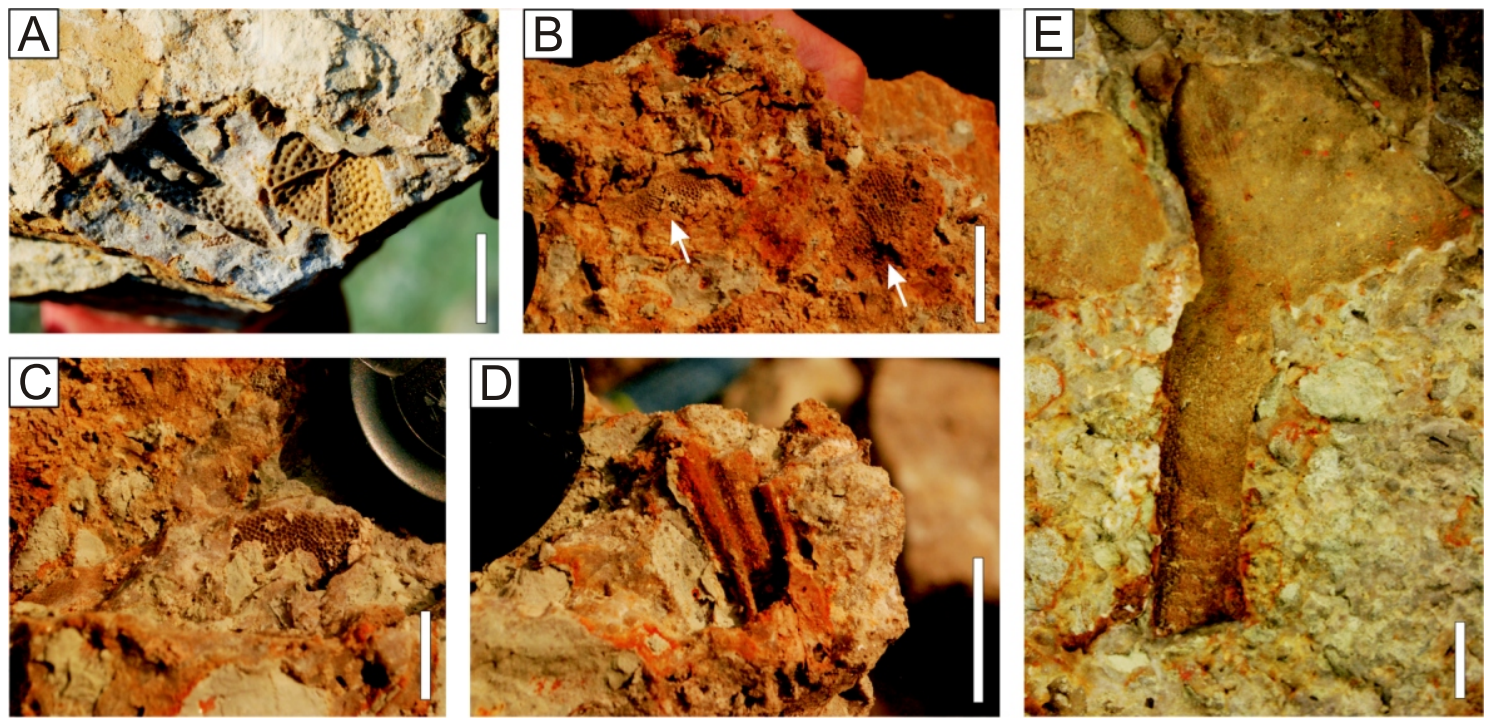

Fig. 5. Photographs of bone breccia specimens as discovered (all specimens are preserved as natural moulds)

A - two placoderm plates; B - large clay clasts in breccia with two remains of heterostracans; C - rounded heterostracan plate with clay clasts and local mudstones accumulation; D - partially preserved acanthodian spine; $\mathbf{E}$ - large bone element from acanthodian girdle; scale bar is $0.5 \mathrm{~cm}$ 

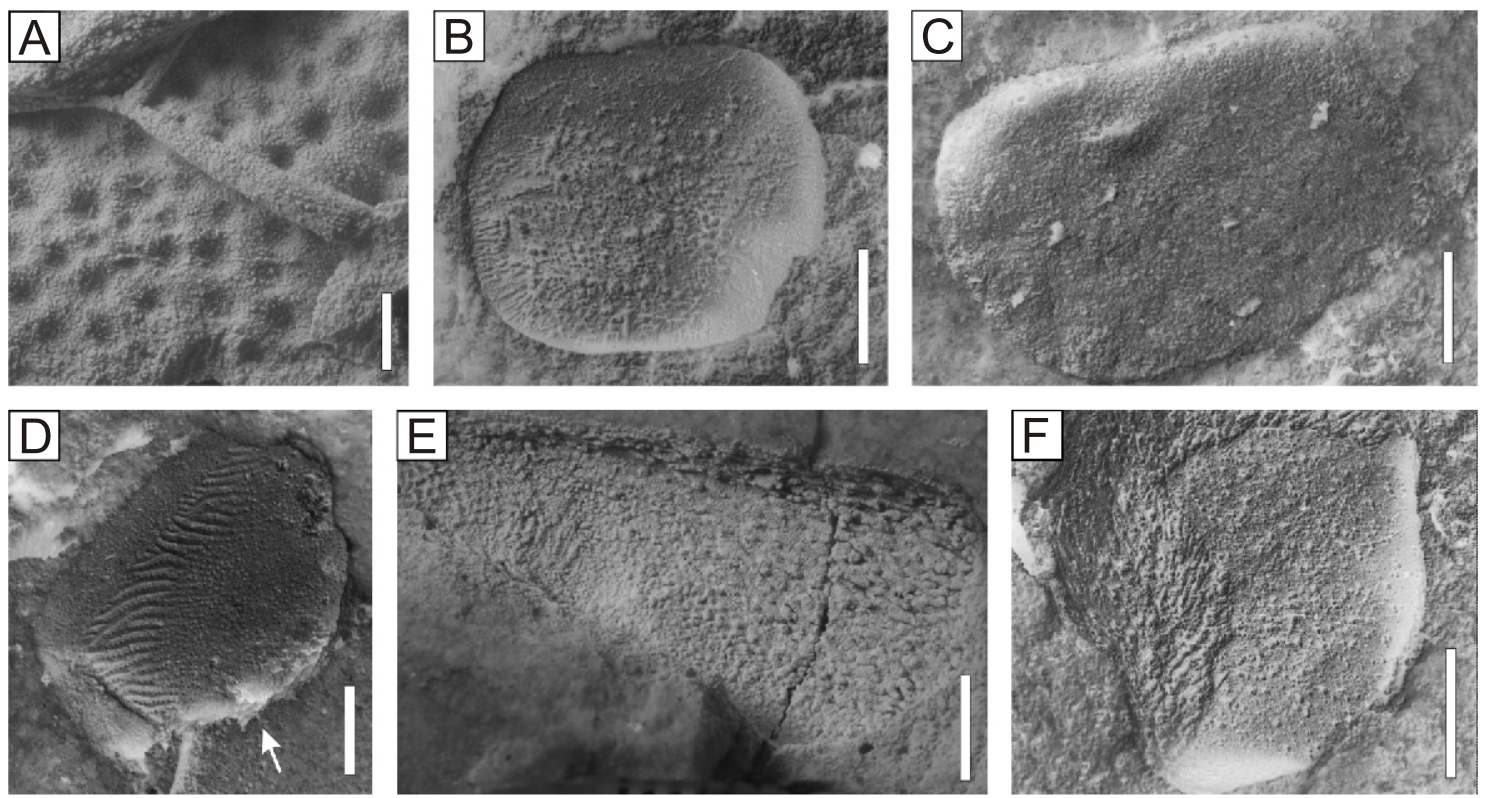

Fig. 6. Fish elements from the bone-bearing breccia

A - placoderm plate with ornamentation (microsculpture) and casts of sensory lines; $\mathbf{B}$ - dermal elements of bony fish with local abrasion; C - highly rounded and abraded bone element; D - sarcopterygian scale with broken margin; E highly abraded skeletal element which shows the internal structure of the bone; $\mathbf{F}$ - partially eroded dermal element of a bony fish; scale bar is $0.5 \mathrm{~cm}$

marked by clay intraclasts, or followed upwards by pebble conglomerate and breccia rich in vertebrate remains (facies A). This conglomeratic interval passes up into either massive, structureless sandstones (facies B), which is overlain by cross-stratified sandstones (facies D), or plane parallel-laminated and ripple cross-laminated sandstones (facies C). Each unit is capped with a massive, usually structureless claystones bed (facies E).

The laminated claystone indicates deposition by suspension fallout in a low-energy environment, such as a coastal lagoon or bay. The cross-stratified and ripple cross-laminated sandstones were deposited from moderate to weak and commonly waning traction currents. The breccia, conglomerate and massive sandstone facies can be interpreted as the infillings of storm gullies that crossed the shallow lagoonal environment.

\section{INVERTEBRATE TRACE FOSSILS FROM THE PODŁAZIE HILL SECTION}

An interval rich in invertebrate trace fossils was identified in a fine-grained sandstones showing horizontal and low-angle inclined lamination. which is interpreted here as hummocky cross stratification (Fig. 3A-C). The specimens described are housed in the collection of the Geological Museum of the Polish Geological Institute-National Research Institute, Warszawa (collection Muz. PGI 1755.II).

chnogenus Lockeia (James, 1879)

Lockeia isp.

(Fig. 3A)
M a t e ri a I. - One slab, Muz. PGI 1755.II.174 (surface with numerous resting traces and short locomotion trails) and field observations.

Description. - Bilaterally symmetrical or slightly asymmetrical, almond-shaped, rarely oval with smooth margin mounds, $6 \mathrm{~mm}$ long and up to $4 \mathrm{~mm}$ wide, preserved as convex hyporelief. A few specimens show a distinct median crest. In the material studied slightly curved and elongate mounds with clearly pointed terminations also occur. A few specimens are associated and fused with elongated traces, probably locomotion trace (Fig. 3A).

features of the ichnogenus Lockeia (see Schlirf, 2000; Schlirf et al., 2001). Lockeia is interpreted as a bivalve resting trace (Seilacher and Seilacher, 1994) occurring in marine and non-marine environments since the Cambrian (Buatois and Mángano, 2011). Small crustaceans (e.g., large representatives of conchostraca or ostracoda) can also be potential producers (Bromley and Asgaard, 1979; Pollard, 1981). Lockeia is a common shallow-marine trace fossil and is the typical element of the Cruziana ichnofacies. However, it has also been described from various terrestrial deposits and deep-sea deposits (Buatois and Mángano, 2011).

Ichnogenus Monomorphichnus (Crimes, 1970)
Monomorphichnus i\$p.
(Fig. 3B)

M a t e ri a I. - One slab, Muz. PGI 1755.II.151.

D e s c r i p t i o n. - Convex hyporelief in the form of a series of straight to slightly wavy striae, $1-2 \mathrm{~mm}$ wide, which are organized as a group. Striae are paraltel or subparallel and do not cross each other. In a few places, striae are arranged in dis- 

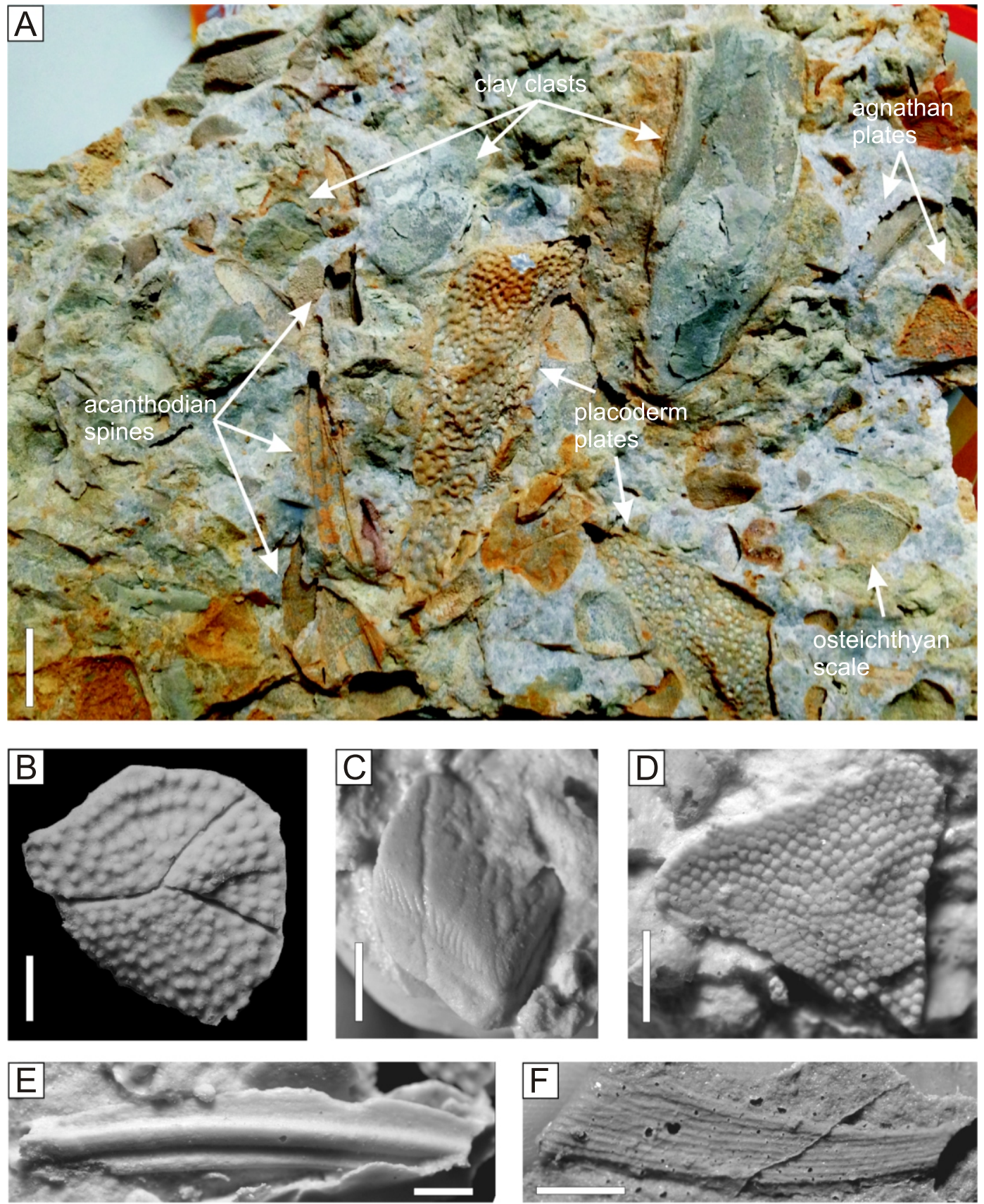

Fig. 7. Skeletal elements from the bone-bearing breccia

A - Muz. PGI 1755.II.153, section through the bone-bearing breccia with numerous vertebrate remains and clay clasts, most of them are marked with arrows; $\mathbf{B}-\mathbf{F}$ - examples of typical remains representing all of the vertebrate groups from the bone-bearing breccia: B - Muz. PGI 1755.II.390, central plate of an actinolepid (Arthrodira, Placodermi), silicon cast, C - Muz. PGI 1755.II.106, scale of Porolepis sp. (Sarcopterygii), D - Muz. PGI 1755.II.484, fragment of heterostracan plate with characteristic ornamentation, E - Muz. PGI 1755.II.360, fin spine of Machaeracanthus sp. (Acanthodii), F - Muz. PGI 1755.II.45, fin spine of chondrichthyan fish; scale bar is $0.5 \mathrm{~cm}$

tinct bundles. The central striae in a bundle are more elevated above the sole than the others.

$\mathrm{R}$ e $\mathrm{m}$ a r k s. - The ichnogenus Monomorphichnus was interpreted a trilobite trace (Crimes, 1970; Fillion and Pickerill, 1990), or one of non-marine crustaceans (Keighley and Pickerill, 1998), or an endemic arthropod (Mikuláš, 1995). Monomorphichnus occurs mainly from the base of the Cambrian (Phycodes pedum zone), but Crimes (1994) suggested that it raises from the Ediacarian. The specimen collected of
Monomorphichnus isp. from Podłazie is very similar to Monomorphichnus podolicus described by Uchman et al. (2004) from the Lower Devonian of Ukraine, which resembles an overlapped Cruziana. According to Uchman et al. (2004) M. podolicus is distinctly different from the other representatives of Monomorphichnus (e.g., Monomorphichnus from the Cambrian) by its densely packed striae and large size. Monomorphichnus from Podłazie is similar to forms described by Fillion and Pickerill (1990). Uchman et al. (2004) interpreted 
such a dense packing of the striae as a grazing trace, probably made by a tracemaker with a large number of grazing appendages (e.g., a trilobite).

Ichnogenus IImenichnus Hecker, 1980 Ilmenichnus jsp.

$$
\text { (Fig. 3C) }
$$

$\mathrm{M}$ a t e r i a I. - One fragment of sandstone with a partially preserved specimen, Muz. PGI 1755.II.152.

D e s c r i p t i o n. - The specimen collected is horizontal or slightly oblique to the bedding plane, a partially preserved composed structure with a marginal tube and spreite area (originally it was a U-shaped structure and encircled by the tube). The preserved limb is clearly separated from the spreite infill and contains additional, low ridges on both margins. The area with spreite structure is well-preserved and shows two types of stratification.

$\mathrm{R}$ e $\mathrm{m}$ a r k s. - The ichnogenus IImenichnus is typical of the Cruziana ichnofacies from shallow subtidal to intertidal environments (MacEachern et al., 2007a, b; see also Schlirf, 2000, 2011; Buatois and Mángano, 2011; Knaust, 2013). Recently, Schlirf (2011) and Knaust (2013) proposed two different classifications for U-shaped spreite trace fossils. The procedure of Schlirf (2011) is followed herein. According to this concept, U-shaped structures with a single-spreite lamina and with a vertical or inclined orientation should be named Diplocraterion (made by suspension-feeders). Wedge-shaped structures with double-spreite laminae are Rhizocorallium (made by mixed deposit and suspension feeders), whereas horizontal structures or those that are slightly oblique to the bedding plane are assigned to Ilmenichnus (made by deposit-feeders).

\section{VERTEBRATE FOSSILS FROM THE PODŁAZIE HILL SECTION}

The vertebrate assemblage from the Podłazie Hill site represents a diverse Early Devonian fauna. Such assemblages are well known from other Lower-Middle Devonian sites of Europe as well as from the upper part of this period (e.g., Stensiö, 1932; Vasilkova et al., 2012; Voichychyn, 2012). The assem blage of vertebrate remains from the Podłazie Hill site (Figs. 7 and 8) contains mainly dermal elements of jawless fishes (Agnatha; representatives of Heterostraci: Rhinopteraspis, Guerichosteus and Hariosteus), dermal bones of medium-sized placoderms (actinolepids), spines, scales and dermal bones of large acanthodians (Machaeracanthus sp.), spines of chondrichthyans (Elasmobranchii indet.), dermal and endoskeletal bones, scales and teeth of large and medium-sized sarcopterygians (a porolepid - Porolepis ex gr. posnaniensis and Dipnoa indet.). as well as undeterminable bones of small actinopterygians (see also Tarlo, 1957, 1961 1964, 1965; Kulczycki, 1960; Szrek et al., 2012).

The heterostracan fossils found in the Podłazie Hill show similarities to the Middle Devonian Baltic forms (Tarlo, 1957) They are represented by fully disarticulated dermal elements, as well as by the plate fragments of heterostracans and placoderms. Scales and teeth, bones of the head and shoulder girdle of osteichthyans, and acanthodian spines and scales are rare, but in some beds they are preserved in small quantity.

\section{BONE BRECCIA ANALYSIS}

Plates, scales, teeth and other dermal elements, as well as possibly some elements of visceral skeleton derived from the bone breccias are preserved as natural moulds in fine-grained sandstones, forming distinct horizons (up to $15 \mathrm{~cm}$ thick). The quartz grains from bone-bearing sandstones are well-rounded and sorted, and are locally coated by clay or iron minerals. The interstices between grains are usually filled with secondary crystallised quartz, the filling spaces between original grains. As a result of subsequent silicification, the most delicate ornamentation (e.g., sculpture bones) of the fossils is perfectly preserved (Figs. 5A, 6A, D and 7B-D). The plates, spines,

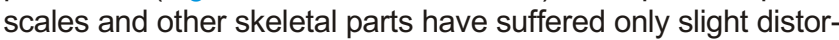
tion, and show such anatomical details as blood vascular canals and microsculpture of spale surfaces and can best be examined from latex or silicon fasts (Fig. 7B-F). This method allows observation of every detait of the bone ahd is easy to apply. Occasionally, small fragments of substance heavily modified by geochemical processes are preserved replacing the original bone.

The bone elements are usually broken (Fig. 6D) ahd their edges are sharp. The collected elements and the casted

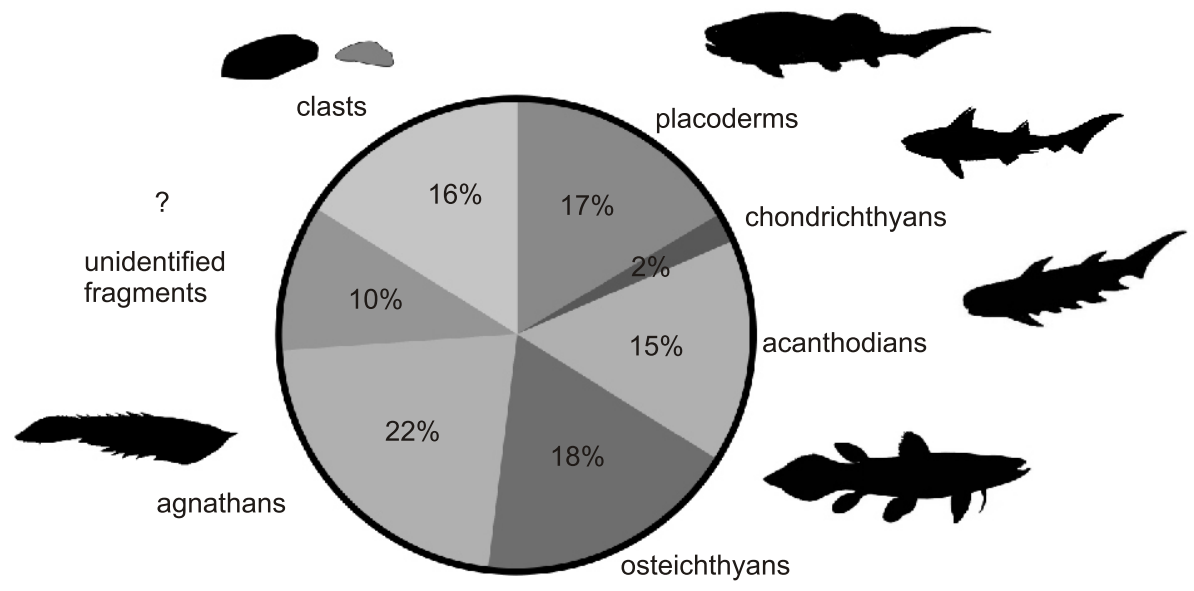

Fig. 8. Graphic illustration of the percentage share of particular vertebrate groups and clasts in the bone-bearing breccia from the Podłazie Hill site 
moulds of vertebrates' bones are not deformed and they maintain the original curvature and shape. Surfaces of the skeletal elements are rarely abraded, although some accumulations is and highly abraded bone elements (Fig. 6B, C, E, F). In mpst cases, they show well-preserved surfaces showing microar atomical features such as delicate ornamentation (Fig. 6A, D), Haver's channels or sensory lines (depending on the vertebrate group). All flat elements such as dermal bones and intraclasts lie horizontally in the deposits and they did not show a vertical orientation. Most skeletal elements are suspended in the sandstone matrix, but a pure bone breccia has also been observed in some places.

The characteristic feature of the bone breccia from the Podłazie Hill site is the great fragmentation of the bone remains mixed with claystone clasts. The horizontal and partly inclined attitude of the bone fragments within the bone-bearing horizon is also not homogeneous. There are zones contrasting in the density of fossil distribution and this probably suggest the periodical accumulation of bone elements on the slopes of subaqueous sand dunes during wave or current activity.

Quantitative analysis of a debris material was made on one solid piece of bone-bearing breccia and all objects seen on the sandstone background were counted (Figs. 7 an 1 8). Each isolated vertebrate fragments, intraclast peble were treated as separate objects. Non-vertebrate remains were treated as separate where their outlines were clear and not in contact with any other object.

Due to the very high degree of fragmentation of almost all vertebrate elements (dermal plates, parts of skulls, flat bones of the endoskeleton, as well as scales and teeth), we decided to count each object individually in spite of the state of preservation. For example, small fragments of dermal plate had the same value as a complete scale during counting.

The identification of vertebrate elements as belonging to a particular group (agnathans, placoderms, chondrichthyans, acanthodians, and osteichthyans) was made based on general, but clearly distinctive morphological features. Such features include ornamentation, shape (outline) of the element, cross-section shape, sensory canals, and internal bone architecture. Typical specimens representing a particular group are presented in Figure 7A-F. Poorly preserved fossils were not assigned to a particular vertebrate group and were classified as unidentified bone fragments.

Counting was based on careful analysis of all specimens collected taken from the breccia bed, considering all objects visible on the surfaces and inside the block. One square metre of a $15 \mathrm{~cm}$ thick breccia bed was analysed. In total, 920 elements were counted. These comprise (Fig. 8) 2 1 1 fragments of agnathans (mostly Psammosteidae, Fo. TD), 166 fragments of osteichthyans (mainly belonging to Porolepis, Fig. 7d),152 remains of placoderms (actinolepids, Fig. 7B), 141 remains of acanthodians (genus Machaeracanth us, Fig. 7E), 19 fradments of chondrichthyans (fin spines of sharks), 93 unidentified bones fragments and 148 intraclasts and quartz pebbles.

Early Devonian vertebrate assemblages are found in many other sites across the Holy Cross Mountains (for example sites from the Iwaniska area and the Podole abandoned quarry near Opatów). They are not easily accessible to make such analysis as at the Podłazie Hill site, however, one may conclude that most of them represent the same origin because of the presence of similar sedimentological characteristics.

\section{DISCUSSION}

Beds with bone concentrations in the Podłazie locality reveal erosional bases. This suggests rapid deposition during high-energy events (Johnson and Baldwin, 2012). This is supported by the state of preservation (abraded bones are rare) that excludes rhythmic reprocessing of the bottom of the sea by wave activity. This interpretation is similar to that for the Middle-Upper Devonian bone-beds from Langsede Cliff, Latvia (Lukševičs et al., 2011) and Klūnas (Vasiljkova et al., 2012)

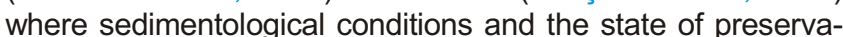
tion of the fossils point to deposition under the influence of rapid water currents. At Langsede Cliff a low rate of fragmentation, but a high degree of bone disarticulation indicate short transport prior to final burial. At the Podłazie Hill site the transport must have been longer or the energy of the transportation process was stronger. Both of these factors must also be taken into consideration because the findings of any complete skeletal elements or even partially articulated bones are extremely rare.

A relatively close analogue to the locality described here is the Bukowa Góra Quarry in the Łysogóry Region of the Holy Cross Mountains, where the Emsian Zagórze Formation (Malec, 1990) is exposed. Our bone-bearing cyclothems broadly resemble graded-laminated sandstone sheets showing brachiopod coquinas along basal scours, described by Szulczewski and Porębski (2008) from this quarry. These sheets were interpreted as storm washovers, which brought shelf invertebrates mixed with marine sands into a muddy, lagoonal backshore.

Concentrations of brachiopods and other marine invertebrates deposited in a lagoonal environment during storm-wave transportation occur commonly at that locality. These shell beds differ from the bone concentration from the Podłazie Hill site in the almost unbroken and non-abraded shelly elements. This may have resulted from lower energy conditions at Bukowa Góra. This is supported by a recent field observation of bone elements found at the Bukowa Góra locality in the shelly concentrations mentioned above (Szrek et al., in press). The bone elements are rare but most of them have natural margins (except the larger elements exceeding $15 \mathrm{~cm}$ across). There is no sedimentological evidence of a lagoonal environment during the deposition of the placoderm sandstone at the Podłazie Hill site.

The composition of the bone-bearing breccia fauna at Podłazie is exclusively of vertebrates, although Czarnocki $(1919,1936)$ and Tarnowska $(1976,1981)$ noted the presence of molluscs, brachiopods and plant detritus (these have never been described and illustrated). Their observations were made at other localities.

Environmental preferences assigned to groups of early/lower vertebrates found in the bone-bearing breccia (based on Janvier, 1996) point to the mixed character of their assemblages. Acanthodians are fishes that lived in the open sea, but placoderms had a wide range of environmental tolerance and in the Early Devonian they occupied mainly marginal-marine, or even brackish environments, such as lagoons or flooded river valleys (see Denison, 1978; Janvier, 1996) to-

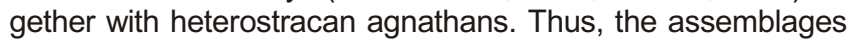
recorded at Podłazie Hill contain forms reworked from the open shelf (acanthodians, chondrichthyans) and mixed with those that lived in a marginal-marine environment (placoderms and sarcopterygians). 
It is likely that the mixed character of the bone assemblages resulted from a high-energy environment during the redeposition and final deposition of faunal remains coming from different ecological niches.

In comparing the environmental tolerances of vertebrates represented in bone-bearing breccia from the Lower Devonian of the Holy Cross Mountains with a particular environment of sedimentation (Tarnowska, 1976) it is essential to determine their position in the profile. Almost all breccias occur wlthin the Upper Sandstone Complex, an informal unit of the Hlaliszka Formation in the Poręba 1 borehole (Tarnowska, 1976). According to Tarnowska (1981) this unit has a transitional sedimentary character defined as a beach and lagoonal zone with a fluvial influence (Tarnowska, 1976). This is generally in agreement with Czarnocki's earlier (1936) view, who suggested a shallow-water, coastal environment for the deposition of the placoderm sandstone. The total absence of body foss ls of invertebrates in the breccia and in the sandstones probably has an environmental character. In this case, this was probably the existence of brackish conditions close to the river mouth. The same sedimentological interpretation was presented by Tarnowska (1976).

Probably most of the Lower Devonian vertebrate bohe beds from the Holy Cross Mountains are associated with a sahdy and claystone deposits and were formed in a marine coas al zone during rapid sedimentation episodes, but differ in foss I abundance and in the state of preservation.

\section{CONCLUSIONS}

The Lower Devonian (Emsian) siliciclastic bone-pearing breccia exposed in the Podłazie Hill locality (Holy Cros\$ Mountains) has yielded rich vertebrate accumulations whose prigin is connected with an open shelf and a marginal-marine setting.

The bone-bearing breccia known as placoderm salhdstone (sensu Gürich, 1896) contains mainly non-placoderm elements belonging to heterostracans, acanthodians, chondrichthyans, and osteichthyans.

The mixed nature of this assemblage, together with an abundance of sedimentological indicators of currents and wave action suggest that the bone-bearing beds were subjected to storm processes affecting coastal areas. Their marine influence is also consistent with the presence of the ichnogenera Monomorphichnus and IImenichnus.

This mixed assemblage is composed of fossil remains which were transported and deposited in shallow-water conditions. During storms the skeletons were broken, segregated, transported, mixed together and transported to shallow-water in the form of reworked sediment enriched with the hard skeletal elements of vertebrates.

The occurrence of the Lockeia, Monomorphichnus, and Ilmenichnus ichnogenera suggests the presence of the Cruziana ichnofacies in the section studied. This may indicate that the siliciclastic, fine- to coarse-grained and vertebrate bone-bearing breccia units originated in a marginal-marine (e.g., lagoonal) environment. However, it remains puzzling why such fossil-rich deposits do not contain groups of organisms such as invertebrates which are usually common. This problem requires further investigation.

Acknowledgements. We thank the Ministry of Science and Higher Education for financial support of our research during 2011-2012 (grant no IP2010 041470). We sincerely thank prof. A. Uchman (Jagiellonian University), prof. G. Racki (University of Silesia), prof. T. Peryt, dr U. Hara (Polish Geological Institute-National Research Institute) and two anonymous reviewers for valuable comments. We are grateful to the Mayor of Daleszyce, Mr W. Furmanek for support and hospitality during fieldworks. We thank also to M. Hodbod and M. Andruszkiewicz-Gorzelak (PGI-NRI, Warsaw), P. Gorzelak (Institute of Paleobiology, Polish Academy of Sciences, Warsaw) and to A. Gronkowska (Warsaw) who helped us during fieldwork. G.N. is currently funded by grant awarded to P.E. Ahlberg (Uppsala University).

\section{REFERENCES}

Bromley, R.G., Asgaard, U., 1979. Triassic freshwater ichnocoenosis from Carlsberg Fjord, East Greenland. Palaeogeography, Palaeoclimatology, Palaeoecology, 28: 39-80.

Buatois, L.A., Mángano, M.G., 2011. Ichnology: the Role of Organism-Substrate Interaction in Space and Time. Cambridge University Press.

Crimes, T.P., 1970. Trilobite tracks and other trace fossils from the upper Cambrian of North Wales. Geological Journal, 7: 47-68.

Crimes, T.P., 1994. The period of early evolutionary failure and the dawn of evolutionary success: the record of biotic changes across the Precambrian-Cambrian boundary. In: The Palaeobiology of Trace Fossils (ed. S.K. Donovan): 105-133. John Wiley and Sons, Chichester.

Czarnocki, J., 1919. Stratygrafia i tektonika Gór Świętokrzyskich (in Polish). Prace Towarzystwa Naukowego Warszawskiego, 28: $1-172$.

Czarnocki, J., 1936. Überblick der Stratigraphie und Paläogeographie des Unterdevons im Polnischen Mittelgebirge. Sprawozdania Państwowego Instytutu Geologicznego, 7: 129-200.
Denison, R.H., 1978. Handbook of Paleoichthyology. Placodermi, vol. 2. Gustav Fischer, Stuttgart-New York.

Fijałkowska-Mader, A., Malec, J., 2011. Biostratigraphy of the Emsian to Eifelian in the Holy Cross Mountains (Poland). Geological Quarterly, 55 (2): 109-138.

Fillion, D., Pickerill, R.K., 1990. Ichnology of the upper Cambrian? to Lower Ordovician Bell Island and Wabana groups of eastern Newfoundland, Canada. Palaeontographica Canadiana, 7: $1-119$.

Głazek, J., Karwowski, Ł., Racki, G., Wrzołek, T., 1981. The early Devonian continental/marine succession at Chęciny in the Holy Cross Mountains, and its paleogeographic and tectonic significance. Acta Geologica Polonica, 31: 233-249.

Gürich, G., 1896. Das Paläozoicum im Polnische Mittelgebirge. Verhandlungen der Russichen-Kaiserlichen Mineralogischen Gesellschaft zu St-Petersburg, 2: 1-539.

Janvier, P., 1996. Early vertebrates. Oxford Monographs on Geology and Geophysics, 33: 1-393. Oxford. 
Johnson, H.D., Baldwin, C.T., 2012. Shallow clastic sea. In: Sedimentary Environments: Processes, Facies and Stratigraphy (ed. H.G. Reading): 232-280. Blackwell Publishing, Oxford.

Keighley, D.G., Pickerill, R.K., 1998. Systematic ichnology of the Mabou and Cumberland groups (Carboniferous) of western Cape Breton Island, eastern Canada. Surface markings. Atlantic Geology, 34: 83-112.

Knaust, D., 2013. The ichnogenus Rhizocorallium: classification, trace makers, palaeoenvironments and evolution. Earth-Science Reviews, 126:1-47.

Kowalczewski, Z., 1971. Main geological problems of the Lowe Devonian in the Świętokrzyskie Mts. (in Polish with English summary). Geological Quarterly, 15 (2): 263-283.

Kulczycki, J., 1960. Porolepis (Crossopterygii) from the Lower Devonian of the Holy Cross Mountains. Acta Palaeontologica Polonica, 5: 65-103.

Lukševičs, E., Ahlberg, P.E., Stinkulis, Ě., Vasil̨kova, J., Zupings, I., 2011. Frasnian vertebrate taphonomy and sedimentology of macrofossil concentrations from Langsçde Cliff, Latvia. Lethaia, 45: 356-370.

MacEachern, J.A., Bann, K.L., Pemberton, S.G., Gingras, M.K., 2007a. The ichnofacies paradigm: high-resolution paleoenvironmental interpretation of the rock record. Applied Ichnology, SEPM Short Course Notes, 52: 27-64.

MacEachern, J.A., Pemberton, S.G., Gingras, M.K., Bann, K.L., 2007b. The ichnofacies concept: a fifty-year retrospective. In: Trace Fossils: Concepts, Problems, Prospects (ed. W. Miller III): 50-75. Elsevier.

Malec, J., 1990. Nowe dane o dewonie Bukowej Góry (in Polish). Kwartalnik Geologiczny, 34 (3): 559-560.

Malec, J., 1993. Upper Silurian and Lower Devonian in the western Holy Cross Mts. Geological Quarterly, 37 (4): 501-536.

Mikuláš, R., 1995. Trace fossils from the Paseky Shale (Early Cambrian Czech Republic). Journal of Czech Geological Society, 40 $37-54$

Narkiewicz, M., Olkowicz-Paprocka, I., 1983. Stratigraphy of the Devonian carbonates in the eastern part of the Góry Świętokrzyskie Mts (in Polish with English summary). Geological Quarterly, 27 (2): 225-256.

Pollard, J.E., 1981. A comparison between the Triassic trace-fossils of Cheshire and south Germany. Palaeontology, 24 555-588.

Schlirf, M., 2000. Upper Jurassic trace fossils from the Boulonnais (northern France). Geologica et Palaeontologica, 34: 145-213.

Schlirf, M., 2011. A new classification concept for U-shaped spreite trace fossils. Neues Jahrbuch für Geologie und Paläontologie Abhandlungen, 260: 33-54.

Schlirf, M., Uchman, A., Kümmel, M., 2001. Upper Triassic (Keuper) non-marine trace fossils from the Hagberge area (Franconia, south-eastern Germany). Paläontologische Zeitschrift, 75: 71-96.

Seilacher, A., Seilacher, E., 1994. Bivalvian trace fossils: a lesson from actuo-paleontology. Courier Forschungsinstitut Senckenberg, 169: 5-15.
Stensiö, E., 1932. The Cephalaspids of Great Britain. British Museum (Natural History), London.

Szrek, P., Niedźwiedzki, G., Dec, M., 2012. The Lower Devonian marginal-marine ecosystems of the Holy Cross Mountains, Poland - new discoveries and observations. Geophysical Research Abstracts, 14, EGU2012-4911 (electronic version).

Szrek, P., Dec, M., Niedźwiedzki, G., in press. The first placoderm fish from the Lower Devonian of Poland. Journal of Vertebrate Paleontology.

Szulczewski, M., 1995. Depositional evolution of the Holy Cross Mountains in the Devonian and Carboniferous - a review. Geological Quarterly, 39 (4): 471-488.

Szulczewski, M., Porębski, S., 2008. Stop 1 - Bukowa Góra, Lower Devonian. In: Ichnological Sites of Poland. The Holy Cross Mountains and the Carpathian Flysch. The Second International Congress on Ichnology, Cracow, Poland, August 2-September 8, 2008. The Pre-Congress and Post-Congress Field Trip Guidebook (eds. G. Pieńkowski and A. Uchman): 18-37. Warszawa.

Tarlo, L.B., 1957. A preliminary note on new ostracoderms from the Lower Devonian (Emsian) of central Poland. Acta Palaeontologica Polonica, 2: 225-233.

Tarlo, L.B., 1961. Rhinopteraspis cornubica (McCoy), with notes on the classification and evolution of the pteraspids. Acta Palaeontologica Polonica, 6: 367-402.

Tarlo, L.B., 1964. Psammosteiformes (Agnatha) - a review with descriptions of new material from the Lower Devonian of Poland. I - general part. Palaeontologia Polonica, 13: 1-135.

Tarlo, L.B., 1965. Psammosteiformes (Agnatha) - a review with de scriptions of new material from the Lower Devonian of Poland. II - systematic part. Palaeontologia Polonica, 15: 1-168.

Tarnowska, M., 1976. Lithological correlation of the Lower Devonian in the eastern part of the Holy Cross Mountains (in Polish with English summary). Biuletyn Instytutu Geologicznego, 296: 75-115.

Tarnowska, M., 1981. Lower Devonian in the central part of the Holy Cross Mountains (in Polish with English summary). Przewodnik 53 Zjazdu Polskiego Towarzystwa Geologicznego, Kielce: 57-67. Instytut Geologiczny.

Tarnowska, M., 1987. Sekwencja osadów niższego dewonu w Dyminach (in Polish). Kwartalnik Geologiczny, 31 (1): 228-229.

Uchman, A., Drygant, D., Paszkowski, M., Porębski, J.S., Turnau, E., 2004. Early Devonian trace fossils in non-marine redbeds in Podolia, Ukraine: palaeoenvironmental implications. Palaeogeography, Palaeoclimatology, Palaeoecology, 214: 67-83.

Vasil̨kova J., Lukševičs E., Stinkulis, Ě., Zupings, I., 2012 Taphonomy of the vertebrate bone beds from the Klūnas fossil site, Upper Devonian Tērvete Formation of Latvia. Estonian Journal of Earth Sciences, 61: 105-119.

Voichyshyn, V., 2011. The Early Devonian armoured agnathans of Podolia, Ukraine. Palaeontologia Polonica, 66: 1-211. 